\title{
THE COST OF VIOLENCE ON CHILDREN
}

\section{An Overview}

Violence is a costly commodity, especially to those who are vulnerable and therefore are forced to pay for it. As a group belonging to this category young children pay a very high price for it.

The cost of violence against children is widespread throughout society. Every recognizable act of violence directed towards children has a cost whether it is direct or indirect. Direct costs come from the use of goods and services such as costs incurred in providing health care services and child protection. Indirect costs are incurred from the effects of violence against children that has imputed monetary value even though they do not involve an actual monetary exchange, such as lost care giver income or reduced profits which stem from caring for children during times of crisis (e.g., leave of absence taken to accompany a child who has experienced sexual abuse, for the investigations). The effect of violence against children also includes intangible costs such as death, disability, injuries and severe psychological distress (de Silva, 2000; Somasundaram, 1998; Das, 1990), pain and suffering for which there is no imputed monetary value in the economy of Sri Lanka. Such costs are felt in both the short run, or the long run. This article explores the direct and indirect cost incurred by violence that children experience from varied dimensions such as home, school, television, community and the country.

\section{Introduction}

Definitions of violence describe it as heterogeneous -in etiology, in terms of quality quantity, and impact on its victim. It can take place as a result of impulsive, reactive behaviour or predatory, remorseless aggression and encompasses a broad spectrum of behaviour such as physical, emotional, sexual, economical and spiritual. It can be caused by intoxication from alcohol, psychosis or other neuropsychiatry conditions such as dementia and traumatic head injury (Perry, I997; WHO, 2000).

For this article the author uses the definition of the World Health Organization (2002) in its World Report on Violence and Health which defines violence as: "The intentional use of physical force or power, threatened or actual, against oneself, another person or against a group or community, that either results in or has a high likelihood of

The Sri Lanka Journal of the Humanities XXXVII (I\&2) 2011 
resulting in injury, death, psychological harm, mal development or deprivation" (WHO, 2002; p:5).

The cost of violence against children is enormous, not only in monetary terms but also in personal costs to well being, self esteem and safety. However, some countries have managed to estimate the cost of violence in monetary terms. For instance, Australia in 2009 estimated that violence against women and their children will cost the Australian economy $\$ 13.6$ billion (The National Council to Reduce Violence against Women and their Children, 2009). The World Report on Violence and Health, WHO (2002) is of the opinion that violence against children deeply harms not only its victims, but also their families, friends and communities. Its effects are seen not only in death, illness and disability, but also in terms of the costs of health and welfare services, reduction in productivity, decrease in the value of property, and disruption of a range of essential services.

Therefore, the cost of violence is high. To begin with children cannot protect themselves from the potentially dangerous effects of it. Second, they do not possess the communication skills to explain their feelings and experiences in comparison to older children, and as a result caregivers may not notice their distress, which in turn may contribute to further future victimization of the children. Third, at times adults are under the misperception that very young children are not aware of what goes on around them or that they will forget what they experience. All these assumptions point in the direction of alarming consequences creating a vicious cycle of victims, aggressors and increased potential for criminal acts. In fact, there is evidence that children who behave aggressively with their peers have been victims of some form of violence (Conaway \& Hansen, 1989) and exposure to violence in early childhood leads to potential disruptive behaviour in adolescents and adults (Conduct problem prevention group, 1996; Staub, 1989; Widom, 1989; Wilson \& Hernstein, 1985). Therefore, considering the importance of early experiences of children on later behaviour, there is an urgency to examine the effects of domestic, television, community and political violence on the lives of young children (Staub, 1989).

In the report, "The Economic Costs of Violence against Women" Day, McKenna, \& Bowlus, (2005) categorize the cost of violence against women into four types. They can also be generalized to describe the costs incurred by violence against children. They are: direct and tangible, indirect and tangible, direct and intangible and indirect and intangible.

Direct tangible costs are actual expenses paid; representing real money spent and that therefore can be estinated by their unit cost. Examples for these are transport costs incurred to take children to hospitals, salaries for staff in child protection services and material inputs such a medicine. Indirect tangible are the costs which have monetary value in the economy. However they are measured as a loss of potential. For instance, a parents' productivity may be reduced due to the fact that he or she has to care for a child who has been disabled due to a gang fight in the neighbourhood. This loss of personal income can be calculated by measuring the lost time at work and multiplying it by an appropriate wage rate. Accordingly, direct intangible costs are the direct outcome of the violent act which cannot be given a financial value. They amount to pain, suffering, and the emotional loss of a loved one through a violent death. The costs of these can be measured only approximately. Indirect intangible costs are the ones which result indirectly from the violence, and have no economic value such as the negative psychological effects on 
children who witness violence, long term psychosocial impact on children who experience sexual abuse, and expenses which cannot be estimated numerically.

However, in this article, I explore mainly the direct intangible and indirect intangible costs of violence against children. In order to explain the extent of the costs and consequences of these phenomena I divide them into five major categories: Home, School, Television, Community and the country. These themes are discussed in the context of the cost and consequences they posit for children in Sri Lanka.

\section{i. Domestic Violence}

The term "domestic violence" encompasses a wide spectrum of behaviour, which includes physical, social and psychological abuse perpetrated by both adults and children in family life (Kitzmann, Gaylord, Holt, \& Kenny, 2003). Research contends that conflict which threatens negative emotional security such as marital conflict and domestic violence negatively affects children's understanding of how to function in stressful situations such as conflict situations with peers (Schudlich, Shamir, \& Cumnings, 2004). As a result, children who witness and/or are victims of domestic violence may carry with them negative blueprints of interaction and/or the risk of precipitating other difficult events due to that exposure (Perera, 2009).

The responsibility of parents and family to care for the child is recognized in every society. However, some families tend to overlook this factor due to the discord between the marital partners. As a result, a plethora of research studies reveal that the impact of family as a variable is instrumental in predicting aggression and psychological distress in children (Catani et al, 2010; Perera, 2009; Haj-Yahia, Tishby, \& de Zoysa, 2009; Pathirana, 2006; Kitzmann, et al., 2003). As a consequence, marital aggression has been found to be related to a range of problems within children such as child conduct disorder (Kitzmann, et al,, 2003), personality disorder, inadequacy, immaturity, and clinical levels of problematic child behaviour. It has also been found that very young children seem to be at a greater risk due to their limited understanding of conflict and less developed strategies of coping. Research also posits that there is a strong correlation between marital conflict strategies and children's notions about conflict strategies with peers (Jouriles, Murphy, \& O'Leary, 1989; Schudlich, Shamir, and Cummings 2004). However, research also suggests that domestic violence would not necessarily result in negative parent-child attachment or externalizing problems such as aggressive behaviour (Levendosky, Huth-Bocks, Shapiro, $\&$ Semel, 2003).

However, domestic violence does not occur in isolation. Other factors such as conflict and natural disaster may also trigger and increase the prevalence of domestic violence. Unfortunately for Sri Lankan children, Sri Lanka as a country suffered from the recent major natural disaster Tsunami, and a conflict which prevailed for nearly four decades, which may have resulted in changing the way families functioned as a unit and creating a collective trauma (Somasundaram, 2007), in turn increasing the prevalence of domestic violence. A study carried out on Sri Lankan children who have experienced Tsunami and or conflict found that $96 \%$ of the child participants are reported to have experienced at least one event of domestic violence with an average of more than five family violence event types for the whole sample (Catani. Gewirtz. Wieling. Schauer. Elbert, \& Neuner, 2010). de Soyza (2006) found that 56.3\% of 12-year-old Sri Lanka 
children had witnessed some form of violence between their parents. Another study carried out by Haj-Yahia, and de Zoysa (2008) found that $11 \%$ and $84 \%$ of Sri Lankan students had experienced at least one act of parental psychological aggression, and between $2 \%$ and $22 \%$ had experienced at least one act of parental physical violence during childhood.

Moreover, studies also reveal that children who experience other traumatic events along with the family violence seem to be affected more in comparison to children who do not experience it. Also, family conflict or dysfunctional families is reported as one of the significant risk factors which creates a vulnerability within children to experience other difficult experiences or circumstances such as child sexual abuse (Perera, 2009).

However, not all studies indicate that factors associated with domestic violence are strong determinants of stress and anxiety within children. Fernando, Miller, and Berger (2010) found that inter-parental conflict does not significantly contributing to the psychological and psychosocial distress of children who have been exposed to disasters. Conversely, research conducted by Haj-Yahia, Tishby, and De Zoysa (2009) found that there was a significant association between exposure to family violence (i.e., witnessing interparental violence and experiencing parental violence) during childhood and adolescence and adult posttraumatic stress disorder (PTSD) within a sample of Sri Lankan university students.

Within the realm of domestic violence, violence instigated by parents towards children also needs to be explored. Literature suggests that physical abuse in the form of corporal punishment inflicted by parents on children creates a negative impact (de Soyza, Newcombe, \& 2009; de Silva, 2007). For instance, de Soyza, et al, 2009 found that the experience of parental corporal punishment was shown to be moderately, but significantly, associated with psychological maladjustment in children. This association was enlanced by the child witnessing or experiencing non-parent-to-child violence (eg. domestic, community, teacher and peer violence). This study also revealed that the extent of the child's support network, the nature of the parent-child relationship and the child's attitude to corporal punishment did not significantly alter the association between corporal punishment and psychological maladjustment. Corporal punishment was also moderately, but significantly, associated with child physical abuse.

\section{ii. School violence}

School violence can be defined as various forms of aggressive and antisocial behaviour displayed by children in schools that range from serious physical acts involving the use of lethal weapons (Cantor \& Wright, 2002) to less serious physical behaviour like shoving and pushing (Juvonen, 2001), acts that result in emotional harm and hurting others' feelings, like verbal harassment, rumour mongering (Juvonen, 2001), verbal threats (Petersen, Pietrzak, \& Speaker, 1996), cheating, lying (Sheehan, Kim, \& Galvin, 2004), and bullying (Nansel, Overpeck, Haynie, Ruan, \& Scheidt, 2003).

In comparison to western societies, Sri Lanka has a teacher centered approach to teaching. Metaphors equating spare the rod and spoil the child are widespread and accepted by the majority of the Sri Lankans (De Silva, 2001; De Silva, de Soyza \& Kannangara, 2000). Though there is an adequate teacher child ratio (UNICEF. 20(18). Sri Lankan teachers do not receive a specific training on positive discipline (Pathirana, 2006) and are 
poorly paid. As a result, general alternative methods of teaching are rare and alternative ways of maintaining discipline and order in the classroom are not common. As a result, children who are considered to be misbehaving in class are caned, or left outside the classroom for long periods. Physical punishment and humiliating treatment are to a large extent accepted by both children and adults. A study carried out by de Silva (2007) found a high prevalence and frequency of corporal punishment in a cross-sectional study of 1226 school children in Colombo. The results of the study suggested that corporal punishment directly predicted to what extent a child would be maladjusted and that non-parent-to-child violence (i.e. domestic, school, peer and community violence) significantly affected this psychological impairment. These findings are not by any means different from the situation in other South Asian countries. Eighty three percent of the Afghanistan children interviewed said they had been slapped, kicked and caned at school. In Pakistan, corporal punishment prevails in more than 40 per cent of government schools and some 35 per cent of private schools (UNICEF, 2001).

Corporal punishment is lawful in schools, as in the illustration of acceptable criminal force in the Penal Code, 341 (Sri Lanka - Country Report, 2011), though Section 2 of Circular No 2005/17, issued by the Ministry of Education in 2005, declares that corporal punishment should not be used in schools. However, as at 2010 this had not been confirmed in legislation (Sri Lanka - Country Report, 2011), though teachers have been made aware that is a punishable offense (de Silva at al, 2003). With this loophole and in the absence of adequate awareness and training in alternative disciplinary strategies teachers and school administrators may be short of information, skills and competencies to eradicate it from schools.

When Pathirana (2008) investigated the pre and post differences in teacher knowledge and attitudes to a child protection program, called "Be Safe", she found that teachers" perceived knowledge of how to create awareness in children about preventing physical abuse clearly increased to a significant level after their training. However, the change in attitudes pertaining to corporal punishment was unclear. Therefore, the result of the study conveys that teachers seem to be in need of more child friendly attitudes pertaining to corporal punishment.

At times, children themselves can act as the perpetrators of violence against other children, which is commonly known as bullying. Studies carried out on bullying indicate that children become victims of violence at the hands of other children in several different ways: as aggressors who initiate violence on victims, as victims who are subjected to violence, and as bystanders, who support violence through instigation, active encouragement and passive acceptance of violence (Staub, 1989; Slaby \& Stringham, 1994).

Victims repeatedly bullied by peers are often reported to have suffered long-term consequences of social rejection, depression, and impaired self-esteem (Olweus, 1993; Straus, 1995). Victims are also at risk of becoming aggressors, by responding to the perceived threat with defensive aggressive attacks, retaliating against their aggressors or becoming perpetrators of aggression against others (McCord, 1983: Widom, 1989; Straus 1991). Also, being high targets of relational aggression may result in emotional difficulties for children such as depression and anxiety in comparison to their non-targeted peers (Crick \& Grotpeter. 1995). Therefore, victims of aggression in early childhood. if not 
helped to respond effectively, are likely to be victimized repeatedly (Patterson, Littman, \& Bricker 1967; Schwartz, Dodge, \& Coie, 1994).

Bystanders (i.e., those who witness conflict among others) often contribute to aggression among other children through direct instigation, active encouragement, or passive acceptance (Staub, 1989; Slaby, Roedell, Arezzo, \& Hendrix, 1994). MusherEizenman et al (2004) found that witnessing peer aggression predicted higher levels of fantasizing about both direct and indirect aggression in school children indicating that witnessing aggressive episodes may enhance the potential for aggression in children.

Aggressors, on the other hand, tend to show other difficult and maladaptive social behaviours, such as tantruns, defiance and failure to cooperate. Persistent aggressive behaviour directed toward peers often leaves the aggressively acting child with few or no positive, stable peer relationships. Research reveals that physical aggression is predictive of peer rejection during the preschool years (Ladd, 1988). Thus, children with aggressive behaviour are at high risk for loneliness and lack of peer support to help them through difficult times (Crick \& Grotpeter, 1995; Crick et al., 1997; Hawkins, 1993; Steinkamp, 1990).

\section{ii. Community Violence}

Community violence can be described as an exposure, as witness or through actual experience (overt/ physical, verbal threats or psychosocial distress due to direct exposure), to acts of interpersonal violence perpetrated by individuals who are not intimately related to the victim (Jenkins \& Bell, 1997; Farver, Xu, Eppe, Fernandez \& Schwartz, 2005). The literature reveals that assaults, shootings, drug and gang related violence come under the realm of community violence. Randolph, Koblinsky, and Roberts (1996) explain community violence as an ecological stressor that interacts with individual, family and school factors.

Studies point out that there is a close association between children's exposure to community violence and their aggressive behaviour (Jenkins et al., 1997). A study conducted by Raviv et al. (2001) with 134 elementary school children in Israel found that levels of exposure to violence were positively associated with subjective distress and also with mother's reports of children's behavioural problems. Though extremely few, studies carried out in Sri Lanka also convey that community violence creates maladjustment and psychological damage within the Sri Lankan children (de Silva, 2007).

Even preschool children seem to be influenced by community violence, and one of the possible potential impacts of community violence is aggression. Randolph et al. (1996) have reported that due to exposure to community violence, children develop aggressive (Pathirana, 2006), impulsive and self-protective behaviour. They further envisage that such behaviour may hinder young children's acquisition of positive values such as cooperation, empathy and sensitivity. A study was conducted by Farver, Natera, and Frosch (1999) with 64 inner city 4-year olds from families that had been personally victimized by acts of community violence such as forced entry into their homes, threatened with physical harm, heard 'gunshots' found that the children in those families were reported to have indicated distress symptoms associated with this exposure to violence. They also found that these episodes of community violence had an adverse effect on their cognitive performance and socio-emotional functioning with peers. 
A study conducted by Farver, Xu, Eppe, Fernandez and Schwartz (2005) with 431 head start preschoolers to investigate the effects of community and family conflict on preschoolers' socio-emotional functioning found that many families and children had witnessed violence in their neighbourhoods. The results of the study revealed that the children's exposure to community violence was positively associated with mother's ratings of children's distress and teacher ratings of their aggressive behaviour.

However, basic descriptive and correlation studies of very young children's response to community violence or of the role played by the family and preschool in protecting children from violence related stress are few, and in Sri Lanka, almost nonexistent.

However, in a study which investigated the impact of violence and abuse experienced by street children in Sri Lanka the author found that the street children who participated in the study have observed at least one event of community violence. Some of the events that they have witnessed were found to be intense such as murders or stabbings (Pathirana, 1999).

The police reports indicate that the prevalence of crime increases each year (Fonseka, 2004). As a result, an increasing number of Sri Lankan children may be victims of community violence. Moreover, due to violence in their neighbourhood, parent may not allow their children to go out and play creating problems related to socio-emotional capacities of the child (Pathirana, 2006; Kostelny \& Dubrow, 1991).

Therefore, based on this evidence it could be said that the cost and the consequences of community violence on children often functions as an invisible factor which may go unnoticed creating a more severe impact than anticipated. Moreover, community violence may also posit several negative impacts within children depriving them of the right to play and recreation due to the terror felt by the parents to allow the children to go out. Further, children who observe violent events are likely to imitate them (Bandura, 1961; Pathirana, 2006). However, due to the absence of empirical findings in the Sri Lankan context it is difficult to deliver predictions on the costs of community violence against children.

\section{iv. Violence on Television}

Very few topics are as widely discussed as the correlation between television violence and aggressive behaviour within children. Research findings reveal that children who viewed aggressive television programs show significantly greater increases in interpersonal aggression from baseline to treatment than do children who viewed non-aggressive programs (Steur, Applifield, \& Smith ,1971). Also, Walker and Morley (1971) found that adolescents who reported liking television violence held more aggressive attitudes. These studies point out that there may be a linear relationship between witnessing television violence and aggression in children. It could also be due to the fact that children's interpersonal aggressive behaviour increased after viewing filmed aggression. Murray (1997) also notes three main effects of television, which he categorizes as the 'Direct effect' (Children and adults who watch a large number of television programs may become more aggressive and/or they may develop favourable attitudes and values about the use of aggression to resolve conflicts). Desensitization (Children who view a large number of violent television programs may become less sensitive to violence in the real world around 
them, less sensitive to the pain and suffering of others, and more willing to tolerate violence in the society), and the 'Mean World Syndrome' (Children or adults who watch a large number of violent episodes on television may begin to believe and perceive the world as mean and dangerous in real life as it appears on the television).

Stein and Friedrich (1972) exposed 97 preschool children to antisocial, pro-social and neutral television programs during a 4-week viewing period. The results revealed that the children who were judged to be initially somewhat aggressive became significantly more aggressive during the aggressive diet condition while children in the pro-social diet condition became less aggressive, more co-operative and showed increased willingness to share with other children. When Williams (1986) evaluated the impact of television violence on children before and after the introduction of television in a Canadian community called 'Notel' (No television) for research purposes, he found that children from 'Notel' town displayed significantly physical and verbal aggressive behaviour after the introduction of the television in comparison to the children in the other towns.

Not only violent television contents but also violent video games are reported to have created a negative impact on young children (Griffith, 1991). However, the causal link between exposure to violent television prograns and potentiality for persistent aggression remains very much in question. In a review of studies that support a null view (violence on television has no significant effect overall on aggressive behaviour) and activation effect, it is indicated that those who were exposed to violent television programs develop enduring aggressive behavioural patterns; Kaplan and Singer (1976) comment however that the literature strongly suggests that scientific data do not consistently link violent television fantasy programming to aggressive behaviour in children. However, they accept that violent television can be a possible cause of human aggression.

Interestingly, a sludy conducted in Sri Lanka in 17 districts by Paranagama, Fernando, and Senarath (2003) in 1736 households do not seem to support the interpretation of Kaplan and Singer (1976). The research team found that a significant percentage of mothers and fathers who answered the survey questionnaire were of the opinion that television is a good source of education, entertainment and information for children while a comparatively fewer percentage of mothers and fathers were of the opinion that television is a nuisance to education. television promotes violence in children, children become stubborn or do not comply with parental commands due to television or that television promotes intolerance among children. Overall, the results of the study seem to point in the direction that parents had a positive opinion about the impact of television on children. However, the qualitative component of the survey revealed that children imitated television programs and heroes in those programs and one child participant had wounded his sibling on the head imitating a television program that they have watched. Another finding from the observations was that parents use television as a babysitter indicating that young children might be exposed to considerable numbers of hours of unsupervised television viewing which may include violent television programmes. Other studies conducted in Sri Lanka have come up with similar findings. When Pathirana (2006) interviewed 23 preschool teachers from varied preschool communities to investigate the impact of violence in the lives of preschool children. she found that preschool children often imitated violent acts from the television and used developmentally inappropriate abusive words that they have learnt from the television. 
Though the review could not identify a significant number of empirical data on the impact of violent television programs on young children in Sri Lanka it is noted that several newspaper articles have reported that a number of young children had been killed or wounded during the past years while trying to imitate television programs. One of the most recent newspaper reports reveals that a 12-year boy was strangled to death while attempting to jump over a pile of rocks as depicted in a television program (Vibhavith, 2005). Therefore, the link between the impact of television programs and aggressive behaviour in children cannot be disregarded and the studies cited above urgently call for empirical data pertaining to Sri Lanka.

\section{$\underline{\text { iv. Political Violence }}$}

Childhood can be considered an extremely dangerous phase taking into account the nature and intensity of violence children are exposed to from different nested structures (home, school, neighborhood, television and country). One of these unfortunate forms is political violence that occurs due to conflict between nations or between identifiable groups within a nation, targeting children as victims, witnesses or aggressors for centuries (Staub, 1989; de Silva, 2000; Somasundaram, 1998; Das, 1990).

Organized violence including war, torture, rape, forceful recruitment of children as soldiers and other severe human rights violations, has been inflicted on Sri Lanka's civilian population, adults and children alike during the past four decades, by various sources of perpetration, including the Sri Lankan Army, the Indian Peace Keeping Force (IPKF), LTTE, JVP, and other Para-militaries.

Consequently, generations of Sri Lankan children have been unfortunate victims of the political violence which prevailed in Sri Lanka (Somasundaram, 1998; Gunarathna, 1990; Das, 1990). Armed groups including the two rebel groups (JVP and LTTE) who had a significant role to play in this conflict also instigated, maintained, and perpetrated violence against children (de Silva, 2003; Keairns, 2003; Gunarathna, 1990, Das, 1990). The LTTE went to the extent of recruiting very young children and even using them as human bombs. The children who were recruited as fighters by the LTTE, were given acyanide capsule to be taken, preventing them from being captured alive. The literature conveys that children experienced severe psychological distress due to the fact that they had to live in constant terror of death (de Silva, 2003; Keairns, 2003). These children who were child soldiers also experienced torture, witnessed incidents of killings, bomb explosions and suicides of other children including their closest friends (Keairns, 2003). The author of the article also has worked with former child soldiers who had told her that they were subjected to physical and emotional maltreatment during the period of their training and servitude.

In addition to instigating terror within their own recruits, the LTTE also used to kill civilian children. For example, on the $2^{\text {nd }}$ of June 1987, the LTTE ambushed a bus carrying 33 novice monks, of whom large numbers were children below 12 years (Lanka Library, 2007). The few who survived this ambush sustained critical injuries with one monk being permanently disabled.

During the second insurrection of the JVP, a large number of adolescents were abducted and killed by unknown groups who were rumoured to be members of the police and army (Jeong-ho \& Voorhls, 2004). During this period the schools were closed and 
children lived in terror of being abducted and were deprived of their right to education and play.

Studies indicate that not only children who are directly affected by political violence, but also children who get exposed to it through indirect sources such as television, newspapers or listening to adults get affected. In a survey carried out to investigate the perceived impact of ethnic violence on the lives of preschool children Pathirana (2006) found that $13 \%$ of the preschool teachers surveyed considered ethnic violence a potential factor which leads to aggressive behaviour within preschool children. Results also revealed that $7 \%$ of the preschool teachers considered it as the most prominent factor leading to aggressive behaviour in preschool children. These findings need to be considered seriously taken in the light given that these preschool teachers represented 18 districts of Sri Lanka.

Pathirana (2006) also interviewed 23 preschool teachers from varied communities and different districts of Sri Lanka, including the North \& the East. She found that, of the preschool teachers interviewed, 39\% said that aggression in preschool children has increased due to factors associated with the ethnic violence. Teachers also said that the nature of the impact of ethnic violence varied from depression to expressions of anger and irritability. In addition, they reported that preschool children displayed a sophisticated knowledge of weapons in appropriate tot their age. Teachers also mentioned that they feel that preschool aged children have become immune to aggressive acts and imitate them due to the frequent exposure to violent events such as bomb explosions at the time. A preschool teacher from the East said that she had to change the location of the preschool several times due to the ongoing conflict between the army and the LTTE. She also said that children in her preschool displayed negative behaviour, which she assumed was the result of witnessing and being exposed to political violence. Another preschool teacher mentioned that some of the preschool children that she came across during a visit to a preschool in the North were sharp enough to identify the difference between the artillery fired by the army and the LTTE. Hence, this information suggests that the cost of political violence in the lives of very young children may also be high and the cost and consequences of violence in older children and adolescents needs a thorough investigation.

Due to the above mentioned factors the author is of the opinion that it is extremely important to investigate the direct and indirect intangible costs and consequences of political violence on the collective unconscious of the Sri Lankan children. Since, political violence has prevailed in Sri Lanka for a significant period, deep seated, collective trauma (Somasundaram, 2007) experienced by generations of large numbers of children need to be investigated and addressed to identify the nature of intervention/s to be provided if required and necessary in the future.

\section{Conclusion}

Violence is a ubiquitous phenomenon. Its costs and consequences are many. As one of its most vulnerable target groups, children seem to suffer more than the adults. Living in a country that has been exposed to conflict for over four decades, Sri Lankan children could be more vulnerable than children living elsewhere. The cost in grief and pain experienced by children is difficult to calculate, due to its invisibility. Though technology has made certain types of violence, such as terrorism, wars, riots and civil unrest, more apparent than they were two or three decades before (WHO, 2002), much more violence against children 
occurs out-of-sight in homes, schools, and child care institutions. Children who are recipients of it are too young, weak or vulnerable to protect themselves or protest. At times they are also pressurized to keep silent about their experiences (WHO, 2002). Though its seems unfair to conclude that all the children who are exposed to the violence suffer its costs, when confronted with empirical evidence it is impossible to ignore the costs of violence on children living in Sri Lanka.

\section{References}

Bandura, A., D Ross, \& S.A. (1961). Transmission of aggression through imitation of aggressive model. Journal of Abnormal and Social Psychology, 63, 575-582 in Green, D. C. (2001). Classics in the history of psychology, Retrieved on $14^{\text {th }}$ of August, 2011, from, http://psychclassics.york.ca/ Bandura/ bobo.htm

Catani, C., A.H. Gewirtz, E. Wieling, E. Schauer, T. Elbert, and F.Neuner (2010). Tsunami, War, and Cumulative Risk in the Lives of Sri Lankan. Schoolchildren. Child Development. Vol 81 (4), pp 1176-1191

Cantor, D., \& M.M. Wright 2002). School crime patterns: A national profile of US public high schools using rates of crime reported to police. Report on the Study on School Violence and Prevention, Rockville, MD. (ERIC Document Reproduction Service No. 471 867)

Conaway, L.P., \& D.L. Hansen (1989). Social behavior of physically abused and neglected children. A critical review. Clinical Psychology Review, 9, 627-652.

Conduct problem prevention group. (2002). Evaluation of the first three years of the Fast Track Prevention Trial with children at high risk for adolescent conduct problems. Journal of Abnormal Child Psychology, 30, 19-35.

Crick, N.R., \& J.K. Grotpeter (1995). Relational aggression, gender, and socialpsychological adjustment. Child Development, 66, 710-722. Available online at http;//www.jstor.org/ $18^{\text {th }}$ March, 2005.

Crick, N.R., Casas, J., \& M. Mosher (1997). Relational and overt aggression in preschool. Developmental Psychology, 33, 579-588.

Crick, N.R., J.F. Casas, \& H.C. Ku (1999). Relational and physical forms of peer victimization in preschool. Developmental Psychology, 35, 376-385.

Das, V. (1990). "Our work to cry: Your work to listen." In. V. Das, (Eds.). Mirrors of violence. Delhi: Oxford University Press.

Day, T., K. McKenna, \& A. Bowlus (2005). The Economic Costs of Violence Against Women: An Evaluation of the Literature; Expert brief compiled in preparation for the Secretary-General's in-depth study on all forms of violence against women. Retrieved on $10^{\text {th }}$ of August, 2011 from http://www.un.org/womenwatch/daw/vaw/expert.pdf

de Silva, H. (2003). Power games in war and peace: The tragic impact of corruption, violence and impunity on the Sri Lankan child. Colombo, Sharp Graphic House (ISBN 10: 9559525719).

de Silva D.G.H. (2007). Children needing protection: experience from south Asia. Archives in Diseases in Childhood 2007; 92:931-34 doi:10.1136/adc.2006.101196 Retrieved on 14th August, 2011, from, http:/adc.bmj.com/content/92/10/931 
de Silva, H.G.D., P. de Soyza, \& N. Kannangara, (2001). Corporal punishment. Colomobo: National Child Protection Authority publication.

de Zoysa, P. (2006). Parental use of physical force towards school children in the Colombo district: Prevalence, psychosocial correlates \& psychological consequences. Doctoral dissertation (pp. 137-141), University of Colombo, Sri Lanka

de Zoysa, P., P.A. Newcombe, \& L. Rajapakse (2008). "Consequences of parental corporal punishment on 12-year-old children in the Colombo district." Ceylon Medical Journal, 53, 7-9.

Farver, J.A.M., Y. Xu, S. Eppe, A. Fernandez, and D. Schwartz (2005). "Community violence, family conflict, and preschoolers' socioemotional functioning" Developmental Psychology, 41, $160-170$.

Farver, J.M., L.X. Natera, \& D.L. Frosch (1999). "Effects of community violence on innercity preschoolers and their families." Journal of Applied Developmental Psychology, 20, 143-158.

Fernando, G.A., M.E. Miller, \& D.E. Berger (2010). "Growing Pains: The Impact of Disaster-Related and Daily Stressors on the Psychological and Psychosocial Functioning of Youth in Sri Lanka. Child Development." Vol 81 (4), pp 11921210.

Flannery, D.J., A.K. Liau, K.E. Powell, W.Vesterdal, A.T. Vazsonyi, S. Guo, H. Atha, \& D. Embry. (2003). "Initial behavior outcomes for the peace builders: Universal school based violence prevention program." Developmental Psychology, 39, 292308.

Garbarino, J., K. Kostelny, N. \& Dubrow. (1991) No place to be a child: Growing up in a war zone. Lexington. M.A: Lexington Books.

Griffiths, M. (1999). "Violent video games and aggression: A review of literature." Aggression and Violent Behavior, 4, 203-212.

Haj-Yahia, M. M., O.Tishby, \& P. de Zoysa, (2009). "Post traumatic stress disorder among Sri Lankan university students as a consequence of their exposure to family violence." Journal of Interpersonal Violence, 24 (12), 2018-2038.

Huesmann, L.R., L.D. Eron, M.M. Kefkowitz, \& L.O. Walder (1984). "The stability of aggression over time and generations." Developmental Psychology, 20, $1120-1134$.

Jenkins, E. J., \& C.C. Bell (1997). Exposure and response to community violence among children and adolescents. In J. D. Osofsky (Ed.), Children in a violent society (pp. 9-31). New York: Guilford

Jouriles, E.N., C.M. Murphy, \& K.D. O'Leary (1989). "Interpersonal aggression, marital discord, and child problems." Journal of Consultant Clinical Psychology, 57, 453455 .

Juvonen, J. (2001). "School violence: Prevalence, fears, and prevention." Rand Education Issue Paper. Retrieved October 30, 2003, from

http://www.rand.org/publications/IP/IP219

Kaplan, R.M., and R.D. Singer (1976). "TV violence and viewer aggression: A reexamination of the evidence." Journal of Social Issues, 32, 35-70. 
Keairns, Y.E. (2003). "The voices of girl child soldiers Sri Lanka" Quaker United Nations Office. Retrieved on $14^{\text {th }}$ of August, 2011, from http://www.quno.org/newyork/Resources/girlSoldiersSriLanka.pdf

Kitzmann, K.M., N.K. Gaylord, A.R. Holt, \& E.D. Kenny (2003). "Child witness to domestic violence: A meta-analytic review." Journal of Consulting and Clinical Psychology, 71, 339-352.

Kupersmidt, J. B. \& J.D. Coie (1990). "Preadolescent peer status, aggression, and school adjustment as predictors of externalizing problems in adolescence."Child Development, 61, 1350-1362.

Kupersmidt, J. B., \& J.D. Coie (1990). "Preadolescent peer status, aggression, and school adjustment as predictors of externalizing problems in adolescence." Child Development, 61, 1350-1362.

Ladd, G. W., S.H. Birch, \& E.S. Buhs (1999). "Children's social and scholastic lives in kindergarten: Related spheres of influence?" Child Development, 70, 1373-1400.

Ladd, G.W., J.M. Price, \& C.H. Hart (1988). "Predicting preschoolers' peer status from their playground behaviors." Child Development, 59, 986-992.

Lanka Library, "Arantalawa massacre - June 2nd 1987". Retrieved on $11^{\text {th }}$ of August, 2011, from, http://www.lankalibrary.com/phpBB/viewtopic.php?t=3345.

Levendosky, A.A., A.C. Huth-Bocks, D.L. Shapiro, \& M.A. Semel (2003). "The impact of domestic violence on the maternal-child relationship and preschool-age children's functioning." Journal of Family Psychology, 17, 275-287.

McMurran, M. (1999). "Alcohol and violence." Child Abuse Review, 8, 219-230.

Monks, C., R.O. Ruiz, \& E.T. Val, (2002). "Unjustified aggression in preschool." Aggressive Behavior, 28, 458-476.

Murray, J.P. (1997). "Media Violence and Youth." In. J.D. Osofsky (Ed). Children in a Violent Society. New York; Guilford Press.

Nansel, T., M. Overpeck, D. Haynie, W. Ruan, \& P. Scheidt (2003). "Relationships between bullying and violence among US youth." Archives of Pediatrics and Adolescent Medicine, 157, 348-353.

0. Haj-Yahia, M. M., \& P. de Zoysa (2008). "Rates and psychological effects of exposure to family violence among Sri Lankan university students. Child Abuse \& Neglect." The International Journal, 32, 994-1002.

Olweus, D. (1979). "Stability of aggressive reaction patterns in males: A review." Psychological Bulletin, 86, 852-75.

Olweus, D. (1993). Bullying at school: What we know and what we can do. Oxford: Blackwell Publishers.

Olweus, D. (1994). Bullying at school. Cambridge, U.K: Longman.

Pathirana, B.D.D. (2006). Doctoral dissertation (pp. 137-141), "An inquiry into early violence/aggression and prosocial behaviors in preschool children in Sri Lanka to identify appropriate interventions." University of Colombo, Sri Lanka.

Pathirana, B.D.D \& G. Fernando (2006). "Teacher perceptions of ethnic violence on preschool children in Sri Lanka." In. Peradeniya University Research Sessions. November, 2006. University of Peradeniya.

Pathirana, B.D.D (2008). "Investigating improvements of knowledge of Sri Lankan children who have participated in the "Be Safe!" child personal safety program." 
In. Peradeniya University Research Sessions. December, 2008. University of Peradeniya.

Paranagama, D., C.G. Fernando, \& S.M. Senarath(2003). Television and children: Study in Sri Lanka. Colombo: SIGNIS Sri Lanka.

Patterson, G.R., R.A. Littman., \& W. Bricker (1967). "Assertive behavior in children: A step toward a theory of aggression." Monographs of the Society for Research in Child Development, 32, Serial No. 113).

Petersen, G., D. Pietrzak, \& K.M. Speaker, (1996, February). "The enemy within: A national study on school violence and prevention." Paper presented at the annual meeting of the Association of Teacher Educators, St. Louis, MO. (ERIC Document Reproduction Service No. ED 394 907).

Randolph, S.M., S.A. Koblinsky, \& D.D. Roberts (1996). "Studying the role of family and school in the development of African American preschoolers in violent neighborhoods." The Journal of Negro Education, 65, 282-294. Available online at http;//www.jstor.org/ 21 st March, 2005.

Raver, C.C., \& J. Knitzer (2002). Promoting the emotional well-being of children and families policy paper No. 3 ready to enter: what research tells policymakers about strategies to promote social and emotional school readiness among three- and fouryear-old children. Available online at http:// www.nccp.org/ media/ pew02ctext.pdf. Downloaded on 3.12.2005

Raviv, A., O. Erel, N.A. Fox, L.A. Leavitt, A. Raviv, I. Dar, A. Shahinfar, \& C.W. Greenbaum (2001). Individual measurement of exposure to everyday violence among elementary school children across various settings. Journal of Community Psychology, 29, $117-140$.

Rubin, K.H., K.B. Burgess, \& P.D. Hastings (2003). "Predicting preschoolers' externalizing behaviors from toddler temperament, conflict, and maternal negativity." Developmental Psychology, 39, 164-176.

Schudlich, T.D.D.R., H. Shamir, \& E.M. Cummings (2004). "Marital conflict, children's representation of family relationships, and children's disposition towards peer conflict strategies." Oxford, U.K; Blackwell publishing limited.

Shores, R. E., \& J.H. Wehby (1999). "Analyzing the classroom social behavior of students with EBD." Journal of Emotional and Behavioral Disorders, 7, 194199.

Sheehan, K., L. Kim, \& M.S. Galvin, (2004). "Urban children's perceptions of violence.” Archives of Pediatric and Adolescent Medicine, 158, 74-77.

Simonson, T.A., \& W. Strein (1997). "The effects of teachers' verbal behaviors on kindergartners' perceptions of competence." Psychology in the Schools, 34, $363-371$.

Somasundaram, D. (1998). Scarred minds: The psychological impact of war on Sri Lankan Tamils. New Delhi: Sage Publications India Private Limited.

Somasundaram, D., (2001). "War trauma and psychosocial problems: Patient attendees in Jaffna." International Medical Journal, 8(3), 93-197.

Somasundaram, D. (2007). "Collective trauma in northern Sri Lanka: a qualitative Psychosocial-ecological study." International Journal of Mental Health Systems. Vol .I (1), 5, DOI: 10.1186/1752-4458-1-5. retrieved from online on $14^{\text {th }}$ August, 2011, http://www.springerlink.com/content/975106225482xr23/ 
Staub, E. (1989). The roots of evil: The origins of genoside and other group violence. New York: Cambridge University Press.

Stein, A.H., \& L.K. Friedrich, (1972). "Television content and young children's behavior." In. J.P Murray, E.A. Rubinstein, and G.A. Comstock (Eds.). Television and social behavior. Vol 2. Television and social learning 202-317. Washington DC: US Government Printing Press.

Steur, F.B., J.M. Applifield, \& R. Smith (1971). "Televised aggression and the interpersonal aggression of preschool children." Journal of Experimental Child Psychologi: $11,442-447$.

Straus, M.A. (1991). "Discipline and deviance: Physical punishment of children and violence and other crime in adulthood." Social Problems, 38, 133-154.

Tubman, J.G. (1993). "Family risk factors, parental alcoholism and problem behaviors among school age children." Family Relations, 42, 81-86.

UNICEF:Division of Policy and Practice, Statistics and Monitoring Section (2008). Education statistics: Sri Lanka Retrieved on $14^{\text {th }}$ Augusts, 2011, from, http://www.childinfo.org/files/ROSA Sri Lanka.pdf

UNICEF (2001).Corporal punishment in schools in South Asia: Day of general discussion on violence against children Retrieved on $14^{\text {th }}$ Augusts, 2011, from, http://www.childtrafficking.com/Docs/unicef 2001_corporal_punishment in sout hasia 1.pdf

Vermande, M.M., E.J.C.G. van den Oord, P.P.Goudena, \& J. Rispens, (2000). "Structural characteristics of aggressor-victim relationships in Dutch school classes of 4-to5year olds." Aggressive Behavior, 26, 11-31.

WHO. 2000. World Report on Violence and Health. Geneva. Available on line at http://www.who.int/violence injury prevention/violence/world_report/ wrvheng/en/

Widom, C.S. (1989). "The cycle of violence." Science, New Series, 4901 (244). 160 166. Available online at http;//www.jstor.org/ $14^{\text {th }} \mathrm{Feb}, 2005$.

Williams, T.M. (1986). The impact of television. A natural experiment in three communities. New York: Academic Press.

Wilson, J.Q., \& R. Hernstein (1985). Crime and human nature. New York: Simon Schuster.

World Health Organization (2002). World report on violence and health. Krug, E.G., Dahlberg, L.L., Mercy, J.A., Zwi, A.B., and Lozano, R. (Eds.). Geneva: World Health Organization Publication.

BUDDHIPRABHA D. D. PATHIRANA 